\title{
Extraction and Characterization of Collagen from Sand Sea Cucumber (Holothuria scabra)
}

\section{(Ekstraksi dan Karakterisasi Kolagen dari Teripang Pasir (Holothuria scabra))}

\author{
Gita Syahputra $^{1 *}$, Hariyatun ${ }^{1}$, Muhammad Firdaus ${ }^{2}$, Pugoh Santoso ${ }^{3}$, Wien Kusharyoto ${ }^{1}$, Nunik Gustini ${ }^{1}$
}

(Received April 2020/Accepted April 2021)

\begin{abstract}
Sand sea cucumber (Holothuria scabra) is an aquatic product that belongs to Echinodermata, a habitant in almost all Indonesian seas. The main component of the sea cucumber is protein, one of which is collagen. This study aimed to extract and characterize collagen from the species using the acid-base extraction method. The characterization of sea cucumber collagen includes molecular weight, amino acid components, Fourier transform infrared spectrophotometry, and scanning electron microscopy analysis. This study has successfully extracted collagen from the sample using an extraction system: $\mathrm{NaOH} 0.1 \mathrm{M} ; \mathrm{CH}_{3} \mathrm{COOH} 0.1 \mathrm{M}$; and distilled water under $45^{\circ} \mathrm{C}$ treatments, gave $6 \%$ yield. The collagen has a molecular weight $110-130 \mathrm{kDa}$. Based on the infrared spectra, the specific functional groups of the collagen are amide A (3379.29 cm-1), amide B $\left(2924.09 \mathrm{~cm}^{-1}\right)$, amide I (1681.93 cm-1), amide II (1560.41 $\mathrm{cm}^{-1}$ ), and amide III (1249.87 $\left.\mathrm{cm}^{-1}\right)$. The collagen falls into type $\mathrm{I}$. We suggest an alternative resource of collagen from sand sea cucumber, other than poultry and mammals.
\end{abstract}

Keywords: characterization, collagen, extraction, fishery, sand sea cucumber

\section{ABSTRAK}

Teripang pasir (Holoturia scabra) termasuk jenis Echnodermata dari perairan yang memiliki habitat di hampir seluruh perairan Indonesia. Penelitian ini bertujuan mengekstraksi dan mencirikan kolagen dari species tersebut dengan menggunakan metode ekstraksi asam-basa. Karakterisasi kolagen teripang meliputi: bobot molekul, analisis komponen asam amino, spektofotometri inframerah Fouries, dan mikroskopi payaran elektron. Penelitian ini telah berhasil mengekstraksi kolagen dari sampel menggunakan sistem ekstraksi: $\mathrm{NaOH} \mathrm{0,1} \mathrm{M;} \mathrm{CH}_{3} \mathrm{COOH} \mathrm{0,1} \mathrm{M;} \mathrm{dan} \mathrm{air}$ distilasi $45^{\circ} \mathrm{C}$, menghasilkan rendemen $6 \%$. Kolagen yang diperoleh memiliki bobot molekul sekitar $110-130 \mathrm{kDa}$. Berdasarkan data hasil analisis spektrometri inframerah, gugus fungsi khas dari kolagen yang diperoleh adalah amida $A\left(3379,29 \mathrm{~cm}^{-1}\right)$, amida $B\left(2924,09 \mathrm{~cm}^{-1}\right)$, amida I $\left(1681,93 \mathrm{~cm}^{-1}\right)$, amida II $\left(1560,41 \mathrm{~cm}^{-1}\right)$, dan amida III $(1249,87$ $\left.\mathbf{c m}^{-1}\right)$. Hasil tersebut menunjukkan bahwa kolagen teripang pasir $(\boldsymbol{H}$. scabra) memiliki karakteristik kolagen tipe $\mathrm{I}$. Temuan ini mengisyaratkan sumber alternatif kolagen dari teripang, selain dari unggas dan mamalia.

Kata kunci: ekstraksi, karakterisasi, kolagen, perikanan, teripang pasir

\section{INTRODUCTION}

At the time being, the demand for collagen was derived from poultry farms and the mammals' wastes. Commercial collagen generally comes from cows and pigs. Many diseases are found in poultry and mammals recently, such as avian influenza and mad cow. Thus, it is necessary to search for alternative raw materials for collagen production, such as aquatic products. Collagen from the aquatic products has advantages, such as poultry and mammals-related disease-free,

${ }^{1}$ Research Center for Biotechnology, Indonesian Institute of Sciences (LIPI), Jl. Raya Bogor Km. 46 Cibinong, Bogor, Indonesia 16911

2 Balai Bio Industri Laut, Indonesian Institute of Sciences (LIPI), Pemenangan, Lombok Utara, Indonesia 83352

3 Biosafety Level 3 and Clean Room Laboratory, Indonesian Institute of Sciences (LIPI), Jl. Raya Bogor Km. 46 Cibinong, Bogor, Indonesia 16911

* Correspondence author: Email: gitasyahputra@gmail.com relatively high collagen, and halal raw materials. It can use in the food and drug industry (Senadheera et al. 2020). The aquatic products include cork and patin fish (Hardyanti 2014; Wulandari 2016) and sea cucumbers (Abedin et al. 2014; Safithri et al. 2018; Siahaan et al. 2017; Siddiqui et al. 2013a). In the last decade, growing interest among researchers because of their nutritional value, health benefits, and potential medical therapy. Collagen derived from fishery products has a more thermostable superiority and a more tightly collagen structure (Senadheera et al. 2020).

Sea cucumber is an aquatic product belongs to Echinodermata, a habitant in almost all Indonesian seas. The main component of the sea cucumber is protein, including collagen. Collagen from some sea cucumber species in Indonesia has been successfully extracted and characterized, as reported by Alhana et al. (2015) and Fawziya et al. (2016) on the type of gamma sea cucumber (Stichopus variegatus), Gianto et al. (2018) on the type of golden cucumber ( $S$. 
horrens), as well as Nauli (2019) on the type of Paracaudina australis. However, collagen derived from sand sea cucumber (Holothuria scabra) has not been much revealing before.

This study was intended to extract and characterize the collagen from sand sea cucumbers using an acidbase solvent extraction method. The collagen was characterized by molecular weight, amino acid constituents, Fourier transform infrared spectrophotometry, and scanning electron microscopy analysis. The finding would be beneficial to find an alternative resource of collagen from sea cucumber, other than poultry and mammals. The collagen could be applied as the raw material for the food and health industry directly or after processing the collagen hydrolysate that have a short structure $(<5 \mathrm{kDa})$.

\section{MATERIAL AND METHODS}

\section{Sample Preparation}

The sand sea cucumber with a minimum 200-g weight was collected and cultivated from the Marine Bio-Industrial Centers, Research Center for Oceanography, LIPI Lombok. The samples were cleaned from the outer skin and separated between the flesh and belly contents. Afterward, the flesh was washed, cut into dice-size, and dried at $60^{\circ} \mathrm{C}$. The dried material was subsequently ground into powder-sized up to 100 mesh and stored in a desiccator until used in the following experiment.

\section{Collagen Extraction}

The dried powder was extracted for collagen after solvent optimization to obtain the highest extracted yield. This system was based on acid-base extraction with three replicates, as presented in Table 1. The extracted collagen was then freeze-dried.

\section{Molecular Weight Analysis}

The molecular weight of the collagen was determined using the sodium dodecyl sulfatepolyacrylamide gel electrophoresis (SDS-PAGE) analysis. The extract solution was prepared by dissolving the freeze-dried material from each dilution step (D1-D3) of each extraction system (M1-M4) (Table 1) into $60^{\circ} \mathrm{C}$ distilled water to a final concentration of 10 $\mathrm{mg} / \mathrm{mL}$ (Gómez-Guillén et al. 2002; Khiari et al. 2011; Khiari et al. 2013). The pellet residue (P) solution from each extraction system (M1-M4) and catfish skin collagen (KI), and commercial tilapia fish collagen peptide $(\mathrm{KK})$ as controls were also prepared in the same way as the preparation of the collagen extract solution. The solution was further diluted with Laemmli sample buffer (Biorad) containing $\beta$-mercaptoethanol (Sigma) and heated in boiling water for $10 \mathrm{~min}$. The sample and protein marker (Precision Plus Protein ${ }^{\mathrm{TM}}$ Dual Color Standard; Biorad) were electrophoresed in the $4 \%$ stacking gel and $5 \%$ resolving gel (Laemmli, 1970 ) at a $90 \mathrm{~V}$ constant voltage. Then the gel was stained with the Coomassie Brilliant Blue R-250 and destained with the destaining solution I $(40 \%(\mathrm{v} / \mathrm{v})$ methanol, $7 \%(\mathrm{v} / \mathrm{v})$ acetic acid, and $53 \%(\mathrm{v} / \mathrm{v})$ distilled water, and solution II (5\% (v/v) methanol, $7 \%(\mathrm{v} / \mathrm{v})$ acetic acid, and $88 \%(\mathrm{v} / \mathrm{v})$ distilled water.

\section{Amino Acid Composition Analysis}

The amino acid composition analysis was carried out using ultraperformance liquid chromatography (UPLC) Waters quantitatively on the freeze-dried extracted intact collagen. The columns used were ACCQ-Taq Ultra C-18, photodiode array detector (PDA), temperature $49^{\circ} \mathrm{C}$ with a flow rate of $0.5 \mathrm{~mL}$ per $\mathrm{min}$, at a wavelength of $260 \mathrm{~nm}$, and injection volume of $1 \mu \mathrm{L}$. The amino acids analyzed consisted of 15 amino acids: histidine, threonine, proline, tyrosine, leucine, lysine, aspartic acid, glycine, arginine, alanine,

Table 1 Various acid-base systems for the sand sea cucumber collagen

\begin{tabular}{|c|c|c|c|c|}
\hline $\begin{array}{l}\text { Solvent } \\
\text { system }\end{array}$ & $\begin{array}{l}\text { System I } \\
\text { (M1) }\end{array}$ & $\begin{array}{l}\text { System II } \\
\text { (M2) }\end{array}$ & $\begin{array}{l}\text { System III } \\
\text { (M3) }\end{array}$ & $\begin{array}{l}\text { System IV } \\
\text { (M4) }\end{array}$ \\
\hline Solvent I & $0.1 \mathrm{M} \mathrm{NaOH}(1: 10 \mathrm{v} / \mathrm{v})$ & $0.1 \mathrm{M} \mathrm{NaOH}(1: 10 \mathrm{v} / \mathrm{v})$ & EDTA pH: $7.4(1: 10 \mathrm{v} / \mathrm{v})$ & $0.1 \mathrm{M} \mathrm{NaOH}(1: 10 \mathrm{v} / \mathrm{v})$ \\
\hline (D1) & $\begin{array}{l}\text { Homogenization for } 6 \mathrm{~h} \\
\text { at room temperature }\end{array}$ & $\begin{array}{l}\text { Homogenization for } 6 \mathrm{~h} \\
\text { at room temperature }\end{array}$ & $\begin{array}{l}\text { Homogenization for } 6 \mathrm{~h} \\
\text { at room temperature }\end{array}$ & $\begin{array}{l}\text { Homogenization for } 24 \mathrm{~h} \\
\text { at room temperature }\end{array}$ \\
\hline Solvent II & EDTA pH: $7.4(1: 10 \mathrm{v} / \mathrm{v})$ & $0.5 \mathrm{M} \mathrm{CH}_{3} \mathrm{COOH}(1: 10$ & $\mathrm{NaOH} 0,1 \mathrm{M}(1: 10 \mathrm{v} / \mathrm{v})$ & $0.5 \mathrm{M} \mathrm{CH}_{3} \mathrm{COOH}(1: 10$ \\
\hline (D2) & $\begin{array}{l}\text { Homogenization for } 6 \mathrm{~h} \\
\text { at room temperature }\end{array}$ & $\begin{array}{l}\mathrm{v} / \mathrm{v}) \\
\text { Homogenization for } 24 \mathrm{~h} \\
\text { at room temperature }\end{array}$ & $\begin{array}{l}\text { Homogenization for } 6 \mathrm{~h} \\
\text { at room temperature }\end{array}$ & $\begin{array}{l}v / v) \\
\text { Homogenization for } 24 \mathrm{~h} \\
\text { at room temperature }\end{array}$ \\
\hline Solvent III & $0.5 \mathrm{M} \mathrm{CH}_{3} \mathrm{COOH}(1: 10$ & $45^{\circ} \mathrm{C}$ aquadest $(1: 5 \mathrm{v} / \mathrm{v})$ & $0.5 \mathrm{M} \mathrm{CH}_{3} \mathrm{COOH}(1: 10$ & $45^{\circ} \mathrm{C}$ aquadest $(1: 5 \mathrm{v} / \mathrm{v})$ \\
\hline (D3) & $\begin{array}{l}v / v) \\
\text { Homogenization for } 24 \mathrm{~h} \\
\text { at room temperature }\end{array}$ & $\begin{array}{l}\text { Homogenization for } 6 \mathrm{~h} \\
\text { at room temperature }\end{array}$ & $\begin{array}{l}\mathrm{v} / \mathrm{v}) \\
\text { Homogenization for } 24 \mathrm{~h} \\
\text { at room temperature }\end{array}$ & $\begin{array}{l}\text { Homogenization for } 6 \mathrm{~h} \\
\text { at room temperature }\end{array}$ \\
\hline Yield & $6 \%$ & $3.2 \%$ & $3.5 \%$ & $4.8 \%$ \\
\hline
\end{tabular}


valine, isoleucine, phenylalanine, serin, and glutamic acid.

\section{Functional Group Analysis}

The freeze-dried extracted functional group analysis was performed using the Fourier transform infrared (FTIR) Perkin Elmer L1600107 spectrophotometer at a wavenumber of $4000-6500 \mathrm{~cm}^{-1}$, by Attenuated Total Reflectance (ATR).

\section{Collagen Physical Structure Analysis}

The collagen structure was observed using a scanning electron microscope (SEM) Thermo Scientific Quattro S, on the freeze-dried extracted intact collagen. The installation using specimen stub and coated with Au metal using Coater lon. The observation was

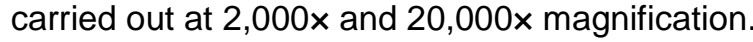

\section{RESULTS AND DISCUSSIONS}

\section{Collagen Extract}

Collagen from aquatic products has been investigated from jellyfish (Rhopilema esculentum), sea urchins (Paracentrotus lividus), and starfish (Acanthaster planci) (Benedetto et al. 2014; Bermueller et al. 2013; Cheng et al. 2017; Tan et al. 2013). Besides, some types of fish have also been successfully used as the source of collagen, including salmon (Salmo salar), tuna (Thunnus albacares), and sardines (Sardinella longiceps) (Alves et al. 2017; Muthumari et al. 2016; Woo et al. 2008). Further research proves the presence of specific biological activity of the collagen that can be beneficial in food and health. Collagen derived from aquatic products is an alternative source for collagen's essential ingredient, commonly derived from pig and cow. Moreover, there is proof of some diseases derived from cow and pig, such as bovine spongiform encephalopathy (BSE), transmissible spongiform encephalopathy (TSE), and foot and mouth disease (FMD), causing many explorations trying to find new sources of collagen, including from aquatic products.

In general, extraction in this experiment was carried out under a maceration system using three solvents (Table I) and subsequent collagen separation employing protein purification technique. This study reported that system IV gave the highest collagen yield from the sand sea cucumber, i.e., $6 \%$ dry weight. The comparison of this yield with previous studies was shown in Table 2. Specifically, this result was lower than the yield from gamma sea cucumber ( $S$. variegatus) (Khirzin et al. 2016). Nevertheless, this result was higher than the average yield from gold sea cucumber (S. hermanii) by Safithri et al. (2018). This result was also higher than the extracted collagen yield

Table 2 The comparison of the extracted collagen yield in this research with previous studies

\begin{tabular}{|c|c|c|c|c|c|}
\hline \multirow{2}{*}{ Source of collagen } & \multirow{2}{*}{ Extraction system } & \multicolumn{3}{|c|}{ Yield (\% dry weight) } & \multirow{2}{*}{ Reference } \\
\hline & & Collagen & PDC & & \\
\hline $\begin{array}{l}\text { Gold sea cucumber } \\
\text { (Stichopus hermanii) }\end{array}$ & $\begin{array}{l}\text { Immersion using } 0.1 \mathrm{M} \mathrm{NaOH} \\
\text { Acid-soluble extraction using } 0.5 \quad \mathrm{M} \\
\mathrm{CH}_{3} \mathrm{COOH}\end{array}$ & $0.66 \pm 0.14$ & ND & & $\begin{array}{l}\text { Safithri et al. } \\
\text { (2018) }\end{array}$ \\
\hline $\begin{array}{l}\text { Gamma sea cucumber ( } S \text {. } \\
\text { variegatus) }\end{array}$ & $\begin{array}{l}\text { Concentration using } 0.3 \% \mathrm{NaOH} \text { and } 0.1 \% \\
\mathrm{CH}_{3} \mathrm{COOH}\end{array}$ & 1.5 & ND & & $\begin{array}{l}\text { Alhana et al. } \\
(2015)\end{array}$ \\
\hline $\begin{array}{l}\text { Sea cucumber ( } S \text {. } \\
\text { monotuberculatus) }\end{array}$ & Acid dissolution using $0.5 \mathrm{M} \mathrm{CH}_{3} \mathrm{COOH}$ & 2.63 & ND & & $\begin{array}{l}\text { Zhong et al. } \\
(2015)\end{array}$ \\
\hline $\begin{array}{l}\text { Sand sea cucumber }(H . \\
\text { scabra) }\end{array}$ & System IV (Table 1) & 6 & ND & & This study \\
\hline $\begin{array}{l}\text { Gamma sea cucumber ( } S \text {. } \\
\text { variegates) }\end{array}$ & $\begin{array}{l}\text { Disaggregation using } 0.1 \mathrm{M} \text { Tris- } \mathrm{HCl} \text { pH } 8 \\
\text { and } 4 \text { mM EDTA } \\
\text { Immersion using } 0.1 \mathrm{M} \mathrm{NaOH} \\
\begin{array}{llll}\text { Acid-soluble extraction using } 0.5 & \mathrm{M} \\
\mathrm{CH}_{3} \mathrm{COOH}\end{array}\end{array}$ & 16.40 & ND & & $\begin{array}{l}\text { Khirzin et al. } \\
(2016)\end{array}$ \\
\hline $\begin{array}{l}\text { Sea cucumber (Acaudina } \\
\text { leucoprocta) }\end{array}$ & $\begin{array}{l}\text { Demineralization pretreatment using } 0.2 \mathrm{M} \\
\text { EDTA } \\
\text { Collagen extraction based proteolysis }\end{array}$ & ND & $\begin{array}{l}43,66 \\
0.65\end{array}$ & \pm & Lin et al. (2017) \\
\hline $\begin{array}{l}\text { Sea cucumber ( } S \text {. } \\
\text { monotuberculatus) }\end{array}$ & $\begin{array}{l}\text { Dissolution using } 0.5 \mathrm{M} \mathrm{CH}_{3} \mathrm{COOH} \\
\text { Collagen extraction based on proteolytic of } \\
\text { pepsin } \\
\text { Pretreatment using } 4 \mathrm{mM} \text { EDTA and } 0.1 \mathrm{M}\end{array}$ & ND & 61.93 & & 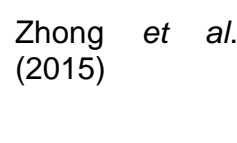 \\
\hline $\begin{array}{l}\text { Sea cucumber } \\
\text { (Bohadschia bivitatta) }\end{array}$ & $\begin{array}{l}\text { Tris- } \mathrm{HCl} \mathrm{pH} 8.0 \\
\text { Collagen extraction using } 0.5 \mathrm{M} \mathrm{CH}_{3} \mathrm{COOH} \\
\text { containing pepsin }\end{array}$ & ND & 65 & & $\begin{array}{l}\text { Siddiqui et al. } \\
\text { (2013) }\end{array}$ \\
\hline $\begin{array}{l}\text { Sea cucumber }(H . \\
\text { cinerascens) }\end{array}$ & $\begin{array}{l}\text { Decomposition using } 0.5 \mathrm{~N} \mathrm{NaCl}, 50 \mathrm{mM} \\
\text { EDTA, } 0.2 \mathrm{~N} \beta-134 \text { mercaptoethanol, and } \\
0.1 \mathrm{~N} \text { Tris- } \mathrm{HCl} \mathrm{pH} 8 \\
\text { Collagen extraction based on pepsin } \\
\text { proteolysis with } 0.5 \mathrm{~N} \mathrm{CH}_{3} \mathrm{COOH}\end{array}$ & ND & 72.2 & & Li et al. (2019) \\
\hline
\end{tabular}


from gamma sea cucumber with the best treatment of various treatments by Alhana et al. (2015). This result was even higher than the yield from sea cucumber $(S$. monotuberculatus) by Zhong et al. (2015). Further, several other studies had successfully extracted pepsin-dissolved collagen (PDC) from various types of sea cucumber, such as Bohadschia bivitatta (Siddiqui et al. 2013b), S. monotuberculatus (Zhong et al. 2015), Acaudina leucoprocta (high purity; Lin et al. 2017), and $H$. cinerascens (Li et al. 2019), with a higher yield than the result from this investigation.

The collagen extraction from the sand sea cucumber in this research generally has a relatively similar process to the commonly known collagen extraction steps, in which pretreatment is followed by extraction. The pretreatment step in this study used 0.1 $\mathrm{M} \mathrm{NaOH}$, intending to remove proteins other than collagen, pigment, and fat, which could interfere with the collagen extraction (Nagai et al. 2002). Furthermore, the extraction was carried out through maceration with $0.5 \mathrm{M} \mathrm{CH}_{3} \mathrm{COOH}$ and $45^{\circ} \mathrm{C}$ distilled water. The maceration step with $0.1 \mathrm{M} \mathrm{CH}_{3} \mathrm{COOH}$ was aimed to dissolve the acid-dissolved collagen, and with an increase of up to $0.5 \mathrm{M} \mathrm{CH}_{3} \mathrm{COOH}$ showed an increase in the extracted yield (Sadowska et al. 2003). The maceration step with the distilled water helps to cleave the peptide bonds in the collagen, thereby easing the subsequent extraction process. The result of the freeze-dried extracted collagen of the sand sea cucumber is shown in Figure 1.

\section{Molecular Weight Analysis}

The purpose of SDS-PAGE analysis was to determine the molecular weight of the collagen. Khiari et al. (2014) reported that characteristic bands, i.e., $\alpha 1$ and $\alpha 2$ monomeric chains, on the SDS-PAGE analysis indicate that collagen is classified into type I. Zhong et al. (2015) also showed that the sea cucumber collagen is a type I collagen with a triple-helix structure formed by three chains of $\alpha 1$ homologous (trimer) with a molecular weight of $\sim 135-138 \mathrm{kDa}$, in addition to the $\alpha 2$ chain. The result of the SDS-PAGE analysis (Figure

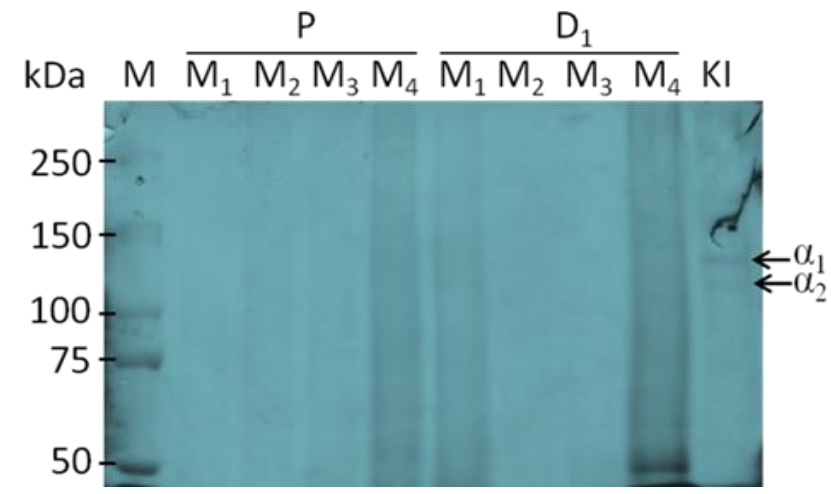

2) showed that among the four systems of the collagen extraction (M1-M4) with gradual dilution using different solvent 1-3 (D1-D3), (Table 1), the extraction system IV (M4) provided better result which showed by the collagen bands at the molecular weight of $\sim 110-130$ $\mathrm{kDa}$ after gradual dilution D3 compared to the bands of the catfish skin collagen (KI) as a control. Whereas there were no collagen bands from the extraction system I-III (M1-M3) at each gradual dilution (D1-D3) nor in the remaining pellet $(P)$ of each system. This result indicated that the sand sea collagen extracted using system IV (M4) in this study has the $\alpha 1$ and a2 chain bands, characteristics of the type I collagen, with a molecular weight $\sim 130 \mathrm{kDa}$ and $\sim 110 \mathrm{kDa}$, respectively. This pattern corresponds to the previous results of the collagen from the body wall of $H$. scabra, which was found to be type I collagen. It contains three homologous $\alpha 1$ chains formed $\alpha 1$ and $\alpha 2$ chains the triple helix as (a1)3 with a molecular weight of 133.2 $\mathrm{kDa}$ (Ram 2017). On the other hand, the extraction through pepsin-solubilized collagen (PSC) from the skin of sea cucumber $H$. parva has a molecular

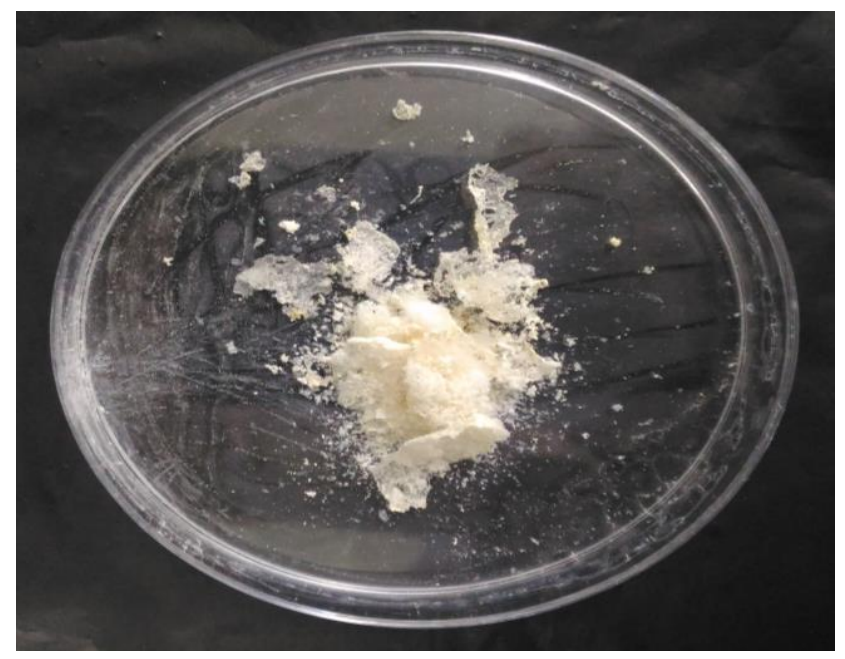

Figure 1 The freeze-dried extracted collagen of the sand sea cucumber ( $H$. scabra).

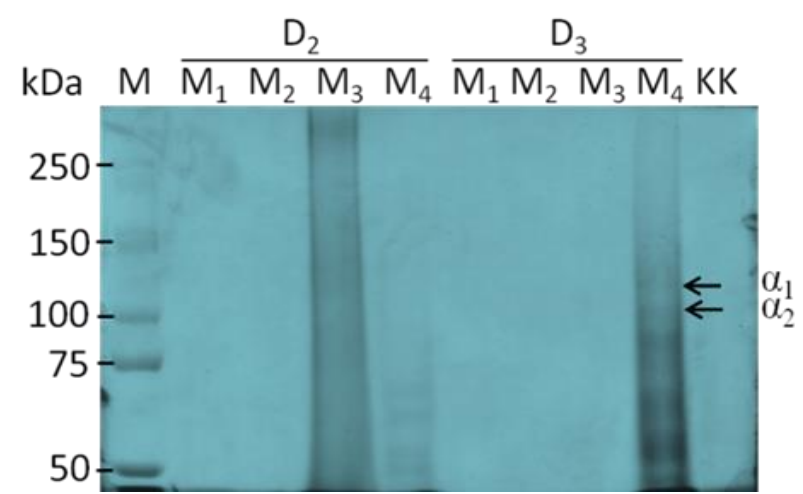

Figure 2 SDS-PAGE profiles of the $H$. scabra collagen. Among the four systems of the collagen extraction used in this research, system IV (M4) provided the best result which showed the collagen band at the molecular weight of $\sim 110-130 \mathrm{kDa}$. $\mathrm{M}$ = protein marker, $\mathrm{P}=$ pellet residue of each extraction system, $\mathrm{D}_{1-3}=$ dilution results of solvent $\mathrm{I}$ III (Table 1), $\mathrm{M}_{1-4}=$ extraction systems I-IV (Table 1 ), $\mathrm{KI}=$ catfish skin collagen, and $\mathrm{KK}=$ commercial tilapia fish collagen peptide. 
structure of ( $\alpha 1) 3$ with a relative molecular mass of 130 $\mathrm{kDa}$ (Adibzadeh et al. 2014). The $\alpha 1$ chain SDS-PAGE pattern of the extracted collagen of the gamma sea cucumber also exhibited type I collagen-containing the main component of the $\alpha 1$ chain with a molecular weight of $\sim 130.33 \mathrm{kDa}$ (Khirzin et al. 2016). Besides, this pattern also corresponds to the results of the PDC extraction from the several types of sea cucumber, such as S. japonicus (Cui et al. 2007), $S$. monotuberculatus (Zhong et al. 2015), and $A$. leucoprocta (Lin et al. 2017). Moreover, Saito et al. (2002) showed that the collagen of the S. japonicus was successfully extracted and characterized as a type I collagen which has two distinct subunits, $\alpha 1$ and $\alpha 2$, and forms a triple-helix heterologous (a1)2a2. Whereas, Abdillah et al. (2017) showed that the collagen from $H$. leucospilota was identified as type I collagen, which has $\alpha 1$ and $\alpha 2$ chains with higher molecular weight the protein bands of the SDS-PAGE result, i.e., 166.43 and $138.35 \mathrm{kDa}$, respectively. $\mathrm{Li}$ et al. (2019) showed that the SDS-PAGE profile of the PDC of $H$. cinerascens belongs to the type I collagen, which contains three chains of $\alpha 1$ chain with smaller molecular weight, i.e., $\sim 80-90 \mathrm{kDa}$. The presence of these SDS-PAGE bands showed that the ( $\alpha 1) 3$ triplehelix structure of the collagen is maintained.

Furthermore, the presence of the other protein bands in the SDS-PAGE indicates a smaller size than the collagen band size, especially in the extract solution from system IV (M4) after gradual dilution D2 and D3, that might represent other structural proteins of the sand sea cucumber body wall that were also extracted during the extraction. Wang et al. (2020) reported that the body wall of Apostichopus japonicus contains structural proteins, which were divided into three divisions, i.e., extracellular matrix (ECM) proteins, muscle proteins, and proteases confirmed by using a proteomics approach. The ECM proteins consist of collagens, proteoglycans, and glycoproteins. Meanwhile, those included in muscle proteins are myosins, actins, troponins, tropomyosin, paramyosin, actin-binding proteins, myosin-binding proteins, titins, obscurins, and twitchins. The last type is proteases consisting of aspartic peptidases, cysteine peptidases, metallopeptidases, serine peptidases, and threonine peptidase. Further, according to Cui et al. (2007), the addition of mercaptoethanol to the SDS-PAGE analysis, which does not affect the band pattern of the $a$-chain, indicates that the $H$. scabra collagen does not have disulfide bonds.

\section{Functional Groups Analysis}

The FTIR analysis for collagen is helpful to show the specific functional groups in the collagen, such as an amide group. Also, the triple-helix structure of the collagen can be indicated by the infrared spectra (Zhong et al. 2015). The functional groups of the sand sea cucumber collagen in the FTIR spectra were detected as amide $\mathrm{A}$, amide $\mathrm{B}$, amide I, amide II, and amide III (Figure 3). The amide A and amide B peaks were observed at a wavenumber of $3379.29 \mathrm{~cm}^{-1}$ and $2924.09 \mathrm{~cm}^{-1}$, respectively (Table 3 ). Amide A resulted from the vibration of $\mathrm{NH}$, while amide $\mathrm{B}$ was formed from the $\mathrm{CH}_{2}$ asymmetry vibration (Coates 2000; Doyle et al. 1975).

Moreover, the absorption of the amide I, which shows the vibration of $\mathrm{C}=\mathrm{O}$, was observed at a wavenumber of $1681.93 \mathrm{~cm}^{-1}$. The amide $\mathrm{I}$ is composed of $\alpha$-helix, $\beta$-sheet, and coil (Kong \& Yu 2007). There were also the amide II and amide III,

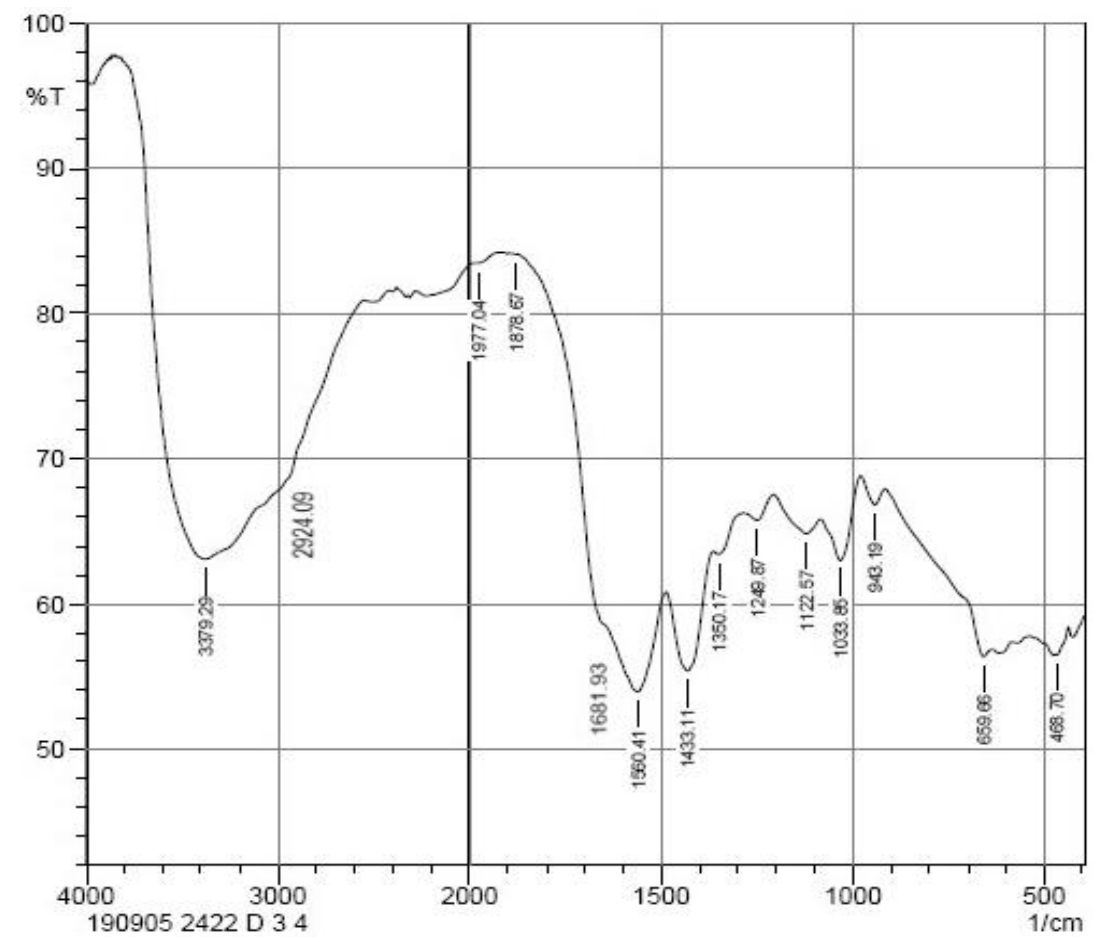

Figure 3 The Fourier-Transform Infrared Spectroscopy (FTIR) spectrum of the $H$. scabra collagen. 
which show $\mathrm{CN}$ stretching and $\mathrm{NH}$ bending, respectively, at a wavenumber of $1560.41 \mathrm{~cm}^{-1}$ and $1249.87 \mathrm{~cm}^{-1}$, respectively (Kong \& Yu 2007). The extracted $H$. scabra collagen had a maintained-intact triple-helix structure characterized by the ratio of the peak spectrum of the amide III, which was close to 1.0 (Matmaroh et al. 2011). Based on these FTIR spectra, the extraction method used did not damage the triplehelix structure of the $H$. scabra collagen. These spectra were also similar to the results of the extracted collagen of the gamma sea cucumber (Alhana et al. 2015), sea cucumber (A. leucoprocta) (Lin et al. 2017), and golden sea cucumber (S. hermanii) (Safithri et al. 2018).

\section{Collagen Physical Structure Analysis}

The physical structure analysis of the sand sea cucumber collagen using SEM was aimed to observe the structure based on the image of the sample surface scanned with a focused-electrons beam. Based on the results of the microscope capture, it was clear that the collagen extracted shows a clot structure that contains the triple-helix structure of the polypeptide of the collagen component (Figure 4). Based on the SEM results, the extraction process of the collagen did not damage the collagen structure.

\section{Amino Acid Composition Analysis}

The determination of the amino acid composition was aimed to evaluate the properties of the collagen, especially in the properties of hydrophobic and hydrophilic amino acids. The amino acids composition of this particular collagen is presented in Table 4. The predominant amino acid composition was glycine, followed by glutamic acid and arginine with a concentration of approximately 557.26, 295.82, and $276.48 \mathrm{ppm}$, respectively. The amino acid composition with the dominant content of the three amino acids was consistent with the result shown in the collagen extracted from the golden sea cucumber (Safithri et al. 2018). Moreover, glycine and glutamic acid as the two primary amino acids contained in the sand sea cucumber collagen, corresponded to the result from the $S$. japonicus (Cui et al. 2007), sea cucumber (S. monotuberculatus) (Zhong et al. 2015), and gamma sea cucumber (Khirzin et al. 2016). Besides, glycine as the most dominant amino acid in the $\mathrm{H}$. scabra collagen residue corresponded to the collagen extracted from the gamma sea cucumber (Alhana et al. 2015), sea

Table 4 The composition of the amino acid of the H. scabra collagen

\begin{tabular}{lc}
\hline \multicolumn{1}{c}{ Amino acid } & Concentration $(\mathrm{ppm})$ \\
\hline Histidine & 4.09 \\
Threonine & 105.16 \\
Proline & 221.57 \\
Tyrosine & 6.69 \\
Leucine & 66.31 \\
Lysine & 46.11 \\
Aspartic acid & 146.28 \\
Glycine & 557.26 \\
Arginine & 276.48 \\
Alanine & 216.42 \\
Valine & 69.95 \\
Isoleucine & 40.89 \\
Phenylalanine & 3.52 \\
Serine & 95.58 \\
Glutamic acid & 295.82 \\
\hline
\end{tabular}

Table 3 The peaks of infrared spectra attributed to the amides of the $H$. scabra collagen

\begin{tabular}{llcl}
\hline \multirow{2}{*}{ Amide } & \multicolumn{2}{c}{ Wavenumber $\left(\mathrm{cm}^{-1}\right)$} & \multirow{2}{*}{ Functional group absorption } \\
\cline { 2 - 3 } & The standard area of absorption & $\begin{array}{c}\text { Absorption of } H \text {. scabra } \\
\text { collagen }\end{array}$ & \\
\hline Amide A & $3440-3400$ (Doyle et al. 1975) & 3379.29 & NH vibration \\
Amide B & $2935-2915$ (Coates 2000) & 2924.09 & $\mathrm{CH}_{2}$ asymmetric vibration \\
Amide I & $1690-1600$ (Kong \& Yu 2007) & 1681.93 & $\mathrm{C}=\mathrm{O}$ vibration \\
Amide II & $1575-1480$ (Kong \& Yu 2007) & 1560.41 & $\mathrm{CN}$ stretching \\
Amide III & $1301-1229$ (Kong \& Yu 2007) & 1249.87 & NH bending \\
\hline
\end{tabular}
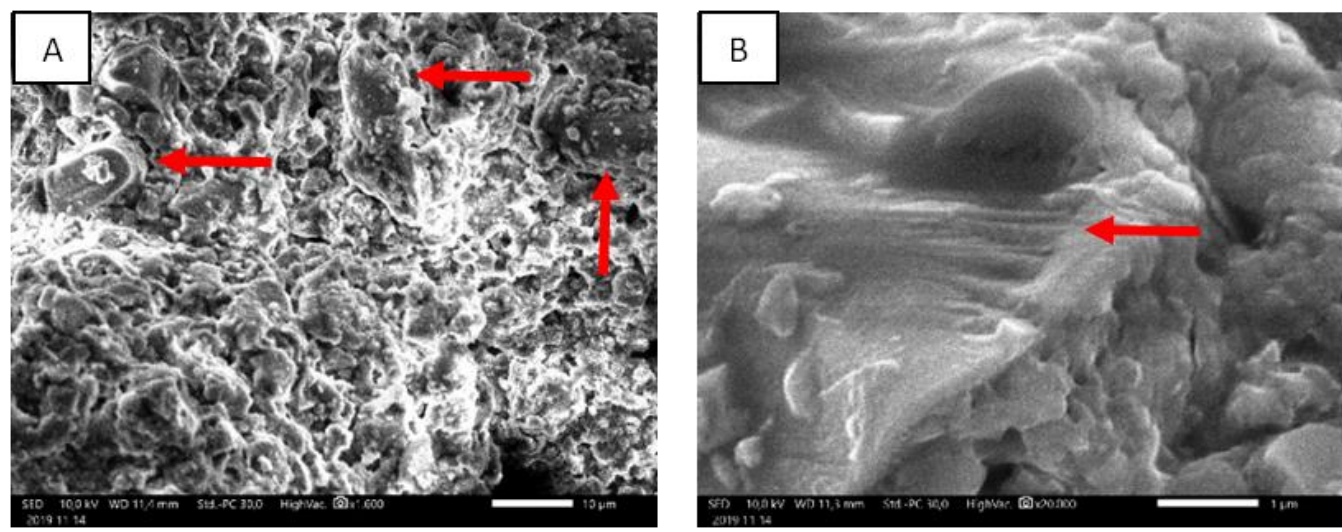

Figure 4 The Scanning Electron Microscopy (SEM) analysis results of the H. scabra collagen structure. A) 2000xmagnification and B) 20000xmagnification. 
cucumber A. leucoprocta (Lin et al. 2017), and sea cucumber $H$. cinerascens (Li et al. 2019). The collagen molecule is a triple-helix polypeptide that forms the Gly$X-Y$ sequence, wherein Gly is glycine, $X$ is proline, and $Y$ is hydroxyproline (Friess, 1998). The abundance of glycine amino acids in $H$. scabra collagen triggers hydrogen bonds in the helix collagen strand (FontaineVive et al. 2009).

\section{CONCLUSIONS}

The collagen of the sand sea cucumber has been extracted, generating a collagen yield of $6 \%$ from dry weight by extraction using maceration with $0.1 \mathrm{M}$ $\mathrm{NaOH}$, followed by $0.5 \mathrm{M} \mathrm{CH} \mathrm{CH}_{3} \mathrm{COOH}$, and a final maceration in $45^{\circ} \mathrm{C}$ distilled water. The collagen has been characterized to have a molecular weight of 110-130 kDa (type I collagen) based on the SDSPAGE analysis. Moreover, characterization with FTIR generated spectral peaks in amide $A\left(3379.29 \mathrm{~cm}^{-1}\right)$, amide B (2924.09 cm-1), amide I (1681.93 cm-1), amide II (1560.41 cm-1), and amide III (1249.87 cm-1). Besides, the SEM analysis result of the sand sea collagen showed that the extraction process did not damage the polypeptide triple-helix collagen structure.

\section{ACKNOWLEDGEMENTS}

This research was funded through Insinas Kemenristek-Dikti program in the fiscal year 2019, entitled "Functional food-based collagen peptide (Holothuria scabra) in assisting essential mineral binding to reduce stunting risk." The authors would like to thank Nina Hermayani Sadi from the Research Center for Limnology, LIPI for the valuable input on the collagen extraction.

\section{REFERENCES}

Abdillah S, Wijiyanti G, Setiawan M, Noor SU, Nurilmala M. 2017. In vitro anti-tyrosinase and antielastase activity of collagen from sea cucumber (Holothuria leucospilota). African Journal of Biotechnology. 16(15). https://doi.org/10.5897/ AJB2016.15655

Abedin MZ, Karim AA, Latiff AA, Gan CY, Ghazali FC, Barzideh Z, Ferdosh S, Akanda MJH, Zzaman W, Karim MR, Sarker MZI. 2014. Biochemical and radical-scavenging properties of sea cucumber (Stichopus vastus) collagen hydrolysates. Natural Product Research. 28(16): 1302-1305. https://doi.org/10.1080/14786419.2014.900617

Adibzadeh N, Aminzadeh S, Jamili S, Karkhane AA, Farrokhi N. 2014. Purification and characterization of pepsin-solubilized collagen from skin of sea cucumber Holothuria parva. Applied Biochemistry and Biotechnology. 173: 143-154 https://doi.org/10.1007/ s12010-014-0823-4

Alhana, Suptijah P, Tarman K. 2015. Ekstraksi dan karakterisasi kolagen dari daging teripang gamma. Jurnal Pengolahan Hasil Perikanan Indonesia. 18(2): 150-161. https://doi.org/10.17844/jphpi.2015.18.2.150

Alves AL, Marques AL, Martins E, Silva TH, Reis RL. 2017. Cosmetic potential of marine fish skin collagen. Cosmetics. 4(4): 39. https://doi.org/ 10.3390/cosmetics4040039

Benedetto $C D$, Barbaglio A, Martinello T, Alongi V, Fassini $D$, Cullorà $E$, Patruno $M$, Bonasoro $F$, Barbosa MA, Carnevali MD, Sugni M. 2014. Production, characterization and biocompatibility of marine collagen matrices from an alternative and sustainable source: the sea urchin Paracentrotus lividus. Marine Drugs. 12(9): 4912-4933. https://doi.org/10.3390/md12094912

Bermueller C, Schwarz S, Elsaesser AF, Sewing J, Baur, N, von Bomhard A, Scheithauer M, Notbohm H, Rotter N. 2013. Marine collagen scaffolds for nasal cartilage repair: prevention of nasal septal perforations in a new orthotopic rat model using tissue engineering techniques. Tissue Engineering Part A. 19(19-20): 2201-2214. https:// doi.org/10.1089/ten.tea.2012.0650

Cheng X, Shao Z, Li C, Yu L, Raja MA, Liu C. 2017. Isolation, characterization and evaluation of collagen from jellyfish Rhopilema esculentum Kishinouye for use in hemostatic applications. PloS ONE. 12(1): e0169731. https://doi.org/10.1371/ journal.pone. 0169731

Coates J. 2006. Interpretation of infrared spectra, a practical approach. Encyclopedia of Analytical Chemistry. https://doi.org/10.1002/9780470027 318.a5606

Cui FX, Xue CH, Li ZJ, Zhang YQ, Dong P, Fu XY, Gao X. 2007. Characterization and subunit composition of collagen from the body wall of sea cucumber Stichopus japonicus. Food Chemistry. 100: 1120-1125. https://doi.org/10.1016/j.foodchem. 2005.11.019

Doyle BB, Bendit EG, Blout ER. 1975. Infrared spectroscopy of collagen and collagen-like polypeptides. Biopolymers. 14(5): 937-957. https:// doi.org/10.1002/bip.1975.360140505

Fawzya YN, Chasanah E, Poernomo A, Khirzin MH. 2016. Isolasi dan karakterisasi parsial kolagen dari teripang gamma (Stichopus variegatus). JPB Kelautan da Perikanan. 11(1): 91-100. https:// doi.org/10.15578/jpbkp.v11i1.284

Fontaine-Vive F, Merzel F, Johnson MR, Kearley GJ. 2009. Collagen and component polypeptides: Low frequency and amide vibrations. Chemical Physics. 
355(2-3): 141-148. https://doi.org/10.1016/ j.chemphys.2008.12.005

Friess W. 1998. Collagen-biomaterial for drug delivery. European journal of pharmaceutics and biopharmaceutics. 45(2): 113-136. https://doi.org/ 10.1016/S0939-6411(98)00017-4

Gianto G, Putri RMS, Suhandana M. 2018. Pengaruh waktu perendaman dan konsentrasi asam asetat terhadap rendemen kolagen teripang emas (Stichoupus horrens). [Internet]. [diunduh 2019 Oktober 23] Tersedia pada: http:// repository.umrah.ac.id/280/1/KARYA\%20ILMIAH.p df.

Gómez-Guillén MC, Turnay J, Fernández-Díaz MD, Ulmo N, Lizarbe MA, Montero P. 2002. Structural and physical properties of gelatin extracted from different marine species: a comparative study. Food Hydrocolloids. 16(1): 25-34. https://doi.org/ 10.1016/S0268-005X(01)00035-2

Hardyanti STK. 2014. Isolasi kolagen dari kulit ikan patin (Pangasius sp.). [Skripsi]. Bogor (ID): Institut Pertanian Bogor.

Khiari Z, Ndagijimana M, Betti M. 2014. Low molecular weight bioactive peptides derived from the enzymatic hydrolysis of collagen after isoelectric solubilization/precipitation process of turkey byproducts. Poultry Science. 93(9): 2347-2362. https://doi.org/10.3382/ps.2014-03953

Khiari Z, Rico D, Martin-Diana AB, Barry-Ryan C. 2011. The extraction of gelatin from mackerel (Scomber scombrus) heads with the use of different organic acids. Journal of FisheriesSciences.com. 5(1): 52-63. https://doi.org/10.3153/jfscom.2011007

Khiari Z, Rico D, Martin-Diana AB, Barry-Ryan C. 2013. Comparison between gelatines extracted from mackerel and blue whiting bones after different pretreatments. Food Chemistry. 139: 347-354. https://doi.org/10.1016/j.foodchem.2013.01.017

Khirzin MH, Sukarno, Yuliana ND, Susanti LY, Chasanah E, Fawziya YN. 2016. Collagen from sea cucumber (Stichopus variegatus) as an alternative source of halal collagen. Proceeding of the 1st International Basic Science Conference (IBSC): Towards the extended use of basic science for enhancing health, environment, energy and biotechnology. 111-113. ISBN: 978-602-60569-55.

Kong J, Yu S. 2007. Fourier transform infrared spectroscopic analysis of protein secondary structures. Acta Biochimica et Biophysica Sinica. 39(8): 549-559. https://doi.org/10.1111/j.17457270.2007.00320.x

Laemmli UK. 1970. Cleavage of structural proteins during the assembly of the head of bacteriophage
T4. Nature. 227(5259): 680-685. https:// doi.org/10.1038/227680a0

Li PH, Lu WC, Chan YJ, Ko WC, Jung CC, Huynh DTL, $\mathrm{Ji}$ YX. 2019. Extraction and characterization of collagen from sea cucumber (Holothuria cinerascens) and its potential application in moisturizing cosmetics. Aquaculture. 515: 734590. https://doi.org/10.1016/j.aquaculture.2019.734590

Lin S, Xue YP, San E, Keong TC, Chen L, Zheng YG. 2017. Extraction and characterization of pepsin soluble collagen from the body wall of sea cucumber Acaudina leucoprocta. Journal of Aquatic Food Product Technology. 26(5): 502-515. https://doi.org/10.1080/10498850.2016.1222560

Matmaroh K, Benjakul S, Prodpran T, Encarnacion AB, Kishimura H. 2011. Characteristics of acid soluble collagen and pepsin soluble collagen from scale of spotted golden goatfish (Parupeneus heptacanthus). Food chemistry. 129(3): 1179-1186. https://doi.org/10.1016/j.foodchem.2011.05.099

Muthumari K, Anand M, Maruthupandy M. 2016. Collagen extract from marine finfish scales as a potential mosquito larvicide. The Protein Journal. 35(6): 391-400. https://doi.org/10.1007/s10930016-9685-7

Nagai T, Nagamori K, Yamashita E, Suzuki N. 2002. Collagen of octopus Callistoctopus arakawai arm. 37(3): 285-289. https://doi.org/10.1046/j.13652621.2002.00568.x

Nauli AP. 2019. Isolasi dan karakterisasi residu kolagen melalui proses perendaman metanol dan air dari teripang (Paracaudina australis). [Thesis]. Surabaya (ID): Universitas Airlangga.

Ram R. 2017. Influence of processing techniques on quality and nutritional composition of the tropical sea cucumber Holothuria scabra. [Thesis]. Australia $(\mathrm{AU})$ : James Cook University.

Sadowska M, Kołodziejska I, Niecikowska C. 2003. Isolation of collagen from the skins of Baltic cod (Gadus morhua). Food Chemistry. 81(2): 257-262. https://doi.org/10.1016/S0308-8146(02)00420-X

Safithri M, Setyaningsih I, Tarman K, Suptijah $P$, Yuhendri VM, Meydia. 2018. Potensi kolagen teripang emas sebagai inhibitor tirosinase. Jurnal Pengolahan Hasil Perairan Indonesia. 21(2): 295-303. https://doi.org/10.17844/jphpi.v21i2. 23085

Saito M, Kunisaki N, Urano N, Kimura S. 2002. Collagen as the major edible component of sea cucumber (Stichopus japonicus). Journal of Food Science. 67(4): 1319-1322. https://doi.org/ 10.1111/j.1365-2621.2002.tb10281.x 
Senadheera TR, Dave D, Shahidi F. 2020. Sea cucumber derived type I collagen: A comprehensive review. Marine Drugs. 18(9): 471. https:// doi.org/10.3390/md18090471

Siahaan EA, Pangestu R, Munandar H, Kim SK. 2017. Review cosmeceuticals properties of sea cucumbers: prospects and trends. Cosmetics. 4(26): 1-12. https://doi.org/10.3390/cosmetics 4030026

Siddiqui YD, Arief EM, Yusoff A, Hamid SSA, Norani TY, Abdullah MYS. 2013a. Extraction, purification and physical characterization of collagen from body wall of sea cucumber Bohadschia bivitatta. Health and the Environment Journal. 4(2): 53-65.

Siddiqui YD, Arief EM, Yusoff A, Suzina AH, Abdullah SY. 2013b. Isolation of pepsin-solubilized collagen (PSC) from crude collagen extracted from body wall of sea cucumber (Bohadschia spp.). International Journal of Pharmacy and Pharmaceutical Sciences. 5(2): 555-559.

Tan CC, Karim AA, Latiff AA, Gan CY, Ghazali FC. 2013. Extraction and characterization of pepsin- solubilized collagen from the body wall of crown-ofthorns starfish (Acanthaster planci). International Food Research Journal. 20(6): 3013-3020.

Wang Y, Tian M, Chang Y, Xue C, Li Z. 2020. Investigation of structural proteins in sea cucumber (Apostichopus japonicus) body wall. Scientific Reports. 10: 18744. https://doi.org/10.1038/ s41598-020-75580-x

Woo JW, Yu SJ, Cho SM, Lee YB, Kim SB. 2008. Extraction, optimization and properties of collagen from yellowfin tuna (Thunnus albacares) dorsal skin. Food Hydrocolloids. 22(5): 879-887. https:// doi.org/10.1016/j.foodhyd.2007.04.015

Wulandari. 2016. Karakterisasi fisikokimia kolagen yang diisolasi dengan metode hidro-ekstraksi dan stabilisasi nanokolagen kulit ikan gabus (Channa striata). [Skripsi]. Bogor (ID): Institut Pertanian Bogor.

Zhong M, Chen T, Hu C, Ren C. 2015. Isolation and characterization of collagen from the body wall of sea cucumber Stichopus monotuberculatus. Journal of Food Science. 80(4): C671-9. 